\title{
New Vigor Methodology in Pearl Millet Seeds
}

\author{
A. S. Suñé ${ }^{1}$, D. B. Rodrigues ${ }^{1}$, A. S. Almeida ${ }^{1}$, C. A. Nunes ${ }^{1}$, L. H. Konzen ${ }^{1}$, E. Gewehr ${ }^{1}$, G. A. Silveira ${ }^{1}$, \\ B. B. Reis ${ }^{1}$, H. L. Chagas ${ }^{1} \&$ L. V. M. Tunes ${ }^{1}$ \\ ${ }^{1}$ Faculdade de Agronomia Eliseu Maciel, Universidade Federal de Pelotas, Capão do Leão, Brazil \\ Correspondence: D. B. Rodrigues, Faculdade de Agronomia Eliseu Maciel, Universidade Federal de Pelotas, Av. \\ Eliseu Maciel s/n, Capão do Leão, Brazil. Tel: 55-5332-757-462. E-mail: ufpelbrandstetter@hotmail.com
}

Received: October 4, 2018

doi:10.5539/jas.v11n4p205

\author{
Accepted: January 11, 2019 Online Published: March 15, 2019 \\ URL: https://doi.org/10.5539/jas.v11n4p205
}

\begin{abstract}
The use of high quality seeds is of utmost importance and is intimately related to seed vigor. The objective of this study was to stablish a novel methodology for evaluating the vigor of pearl millet seeds. The experiment was performed at the Federal University of Pelotas, using 5 seed lots of pearl millet cv. BRS1501. The research was carried out in two stages: first, seed lots were characterized (physiological quality tests); second, the initial emergence and development of pearl millet seedlings was evaluated, testing four different substrates and five sowing depths in the emergence test. The experimental set up consisted of a completely randomized design with four replicates. Means were compared by the Scott-Knott test at the 5\% probability level. The substrates sand and carbonized rice husk, at $1.0 \mathrm{~cm}$ depth, satisfactorily stratified seed lots. These methodologies correlated with the speed of emergency index and seedling emergency. Thus, the study identified an innovative method for testing vigor in pearl millet seeds.
\end{abstract}

Keywords: emergence, forage, Pennisetum glaucum, physiological quality, substrates

\section{Introduction}

Pearl millet [Pennisetum glaucum (L.) R. Br.] is an annual grass of tropical climate which is considered the sixth most important cereal worldwide, due to a great production of fresh and dry matter and high grain and seed yields (Leão et al., 2012). This forage presents high resistance to water deficit, excellent nutritional quality, provides considerable regrowth and good natural reseeding and acceptance by animals.

Several factors, as with all crops, influence seed quality, from the choice of area for sowing to harvest. At physiological maturity the maximum quality of seeds is defined marking beginning of the deterioration process, which can be delayed by appropriate pre and post-harvest management conditions (Nakada et al., 2011).

One of the major problems involving pasture establishment is the variation of seed quality from forage species marketed, especially low-quality seeds. Seed lots which do not meet the minimum standards for production and marketing established by the Ministry of Agriculture, Livestock and Food Supply (MAPA) are considered propagating material or grain (Melo et al., 2016).

Vigor tests are methods used to evaluate or detect significant differences in the physiological quality of seed lots with similar germination, complementing the information provided by the germination test, and to distinguish low and high vigor seeds lots, separating them according to their quality levels (Sousa et al., 2017). Thus, vigor tests shall present characteristics such as speed, simplicity, low cost, reproducibility and provide results.

Despite the recognized importance of fodder production there are practically no vigor tests recommended for such species. Therefore, the adjustment of existing methods and the proposition of alternatives for the characterization of physiological quality is imperative.

Emergency tests are often used to determine seed vigor. However, a substrate which meets all plant requirements is quite uncommon (Melo et al., 2017). Generally, the most suggested substrates are: sand, charred rice husk, sugar cane bagasse and urban waste compost.

This paper describes an innovative methodology for testing vigor of pearl millet seeds. For this purpose, the emergence of seedlings under different substrates and depths of sowing was evaluated. 


\section{Material and Methods}

The experiment was performed at the Didactic Laboratory of Seed Analysis Flávio Farias Rocha from the Universidade Federal de Pelotas. Five seed lots of pearl millet cultivar BRS 1501 were used. The research was carried out in two stages: first, seed lots were characterized; then, seedling emergence and initial development of pearl millet seedlings was evaluated using different substrates and sowing depths.

\subsection{Determination of Seed Physical and Physiological Quality}

Seed lots were characterized regarding physical and physiological aspects using the following tests:

Water content: determined using a kiln at $105 \pm 3{ }^{\circ} \mathrm{C}$ for 24 hours and calculated by the mass difference, based on the wet mass of the seeds. Four replications of $2 \mathrm{~g}$ of seeds were used for each lot, according to the method described by the Rules for Seed Analysis (RAS) (MAPA, 2009). Results were expressed in percentage.

1000-seeds weight: determined by weighing 8 subsamples of 100 seeds from each seed lot. Seeds were manually counted and weighed in an analytical balance with an accuracy of $0.0001 \mathrm{~g}$ (MAPA, 2009). Four replicates were used and the results were expressed in grams.

Germination: performed using four replicates of 200 seeds for each lot (each replicate was evaluated using four subsamples of 50 seeds). Seeds were distributed over two sheets of blotter paper, which were moistened with distilled water at a ratio of 2.5 times the weight of the dry paper, placed into germination boxes (gerbox). The gerboxes were held at $25^{\circ} \mathrm{C}$ and the evaluation was performed on the seventh day after sowing, according to the criteria established in the RAS (MAPA, 2009). Results were expressed as the percentage of normal seedlings.

First count of germination: carried out herewith the germination test, normal seedlings were counted on the fourth day after sowing and the results were expressed as the percentage of normal seedlings.

Accelerated aging: executed using germination boxes $(11.0 \times 11.0 \times 3.5 \mathrm{~cm})$ were $2.0 \mathrm{~g}$ of seeds were disposed in a single layer over a wire mesh which was held suspended above $40 \mathrm{~mL}$ of distilled water. After prepared, the sealed boxes were maintained for 72 hours in BOD (Biochemical Oxygen Demand) at $41^{\circ} \mathrm{C}$ (Tunes et al., 2012). Then, seeds were subjected to the conditions described for the germination test. The evaluations were performed four days after sowing and results were expressed as the percentage of normal seedlings.

Total seedling length: performed using germitest paper which was moistened with 2.5 times the weight of the dry paper with distilled water. Next, at the upper third of the paper, 20 seeds were sown and each paper roll made was held at $25{ }^{\circ} \mathrm{C}$ for four days. The evaluation was carried out using 10 seedlings per replicate, which were randomly selected, measurements used a ruler graduated in millimeters determining total seedling length (TL), shoot length (SL) and root length (RL). The results were expressed in centimeters.

Seedling emergence: tested in raised beds filled with soil from the horizon A of a planosol of the Pelotas mapping unit. For each lot, seeds were randomly distributed in 8 lines of 1.20 meters within each block. Each row received 50 seeds and was spaced by 10 centimeters from the others. Irrigation was performed whenever necessary, or at least once a day, and the evaluation was carried out 21 days after sowing.

Speed of emergence index: performed herewith the seedling emergence test. The number of seedlings emerged each day was counted always at the same time. The parameter for considering seedlings as emerged was at least $3 \mathrm{~mm}$ above the soil surface. Evaluations were carried out until stabilization and the speed of emergence index (IVE) was calculated using the formula proposed Maguire (1962):

$$
\mathrm{SEI}=(\mathrm{E} 1 / \mathrm{N} 1)+(\mathrm{E} 2 / \mathrm{N} 2)+\ldots+(\mathrm{En} / \mathrm{Nn})
$$

where,

$\mathrm{SEI}=$ speed of emergence index; E1, E2, ... En; En = number of normal seedlings counted in each day; N1, $\mathrm{N} 2, \ldots \mathrm{Nn} ; \mathrm{Nn}=$ number of days between sowing and each counting.

The results were expressed as mean indexes of emergency speed for each lot.

This stage was carried out under a completely randomized design with four repetitions.

\subsection{Seedling Emergence and Initial Development of Pearl Millet Seedlings}

Seedling emergence was performed using four different substrates (Sand, CRH, Coconut Fiber and S-10 Beifort $\left.{ }^{\circledR}\right)$ and different sowing depths $(0.5,1.0,1.5,2.0,2.5 \mathrm{~cm})$. The physical and chemical characteristics of the substrates used are presented in Table 1. 
Table 1. Physical and chemical characteristics of the substrates: sand, carbonized rice husk, coconut fiber and S-10 Beifort ${ }^{\circledR}$. Pelotas RS, 2016

\begin{tabular}{|c|c|c|c|c|}
\hline Substrate & Density $(\mathrm{g} / \mathrm{L})$ & Water holding capacity $(\mathrm{mL} / \mathrm{L})$ & $\mathrm{pH}$ & Electric conductivity $\left(\mu \mathrm{S} \mathrm{cm}^{1}\right)$ \\
\hline Sand & 138.00 & 558.50 & 7.0 & 578.9 \\
\hline $\mathrm{CRH}$ & 206.00 & 493.00 & 6.69 & 624.1 \\
\hline Coconut Fiber & 163.12 & 621.50 & 5.70 & 633.6 \\
\hline S-10 Beifort ${ }^{\circledR}$ & 456.51 & 624.00 & 6.42 & 692.0 \\
\hline
\end{tabular}

\subsection{Seedling Emergence in Different Substrates and Depths}

Emergence was performed using 25 seeds from each lot and four replicates which were subdivided and sown into 2 tubes with 10 seeds each. The tubes were filled with the substrates (sand, CRH, CF, S10 Beifort ${ }^{\circledR}$ ) at the depths of $0.5 ; 1.0 ; 1.5 ; 2.0$ and $2.5 \mathrm{~cm}$.

Sand was properly standardized regarding the granulometry using a sieve of $1.6 \mathrm{~mm}$. Afterwards, the sand was washed and shade-dried for 24 hours. The carbonized rice husk was obtained from raw rice husk which was burnt for 4 hours using an adequate barrel with perforations and a cover for better carbonization. Then, the substrate was placed into a metallic bowl and irrigated for cooling which prevents the prolongation of the burning that would result in rice husk ash. The Amafibra ${ }^{\circledR} 47$ Golden Mix standard coconut fiber was purchased from the local market and was pre-moistened 48 hours before the experiment set up. The commercial substrate $\mathrm{S} 10$ Beifort ${ }^{\circledR}$, which is based on agroindustrial organic waste from class A (seed, grape marc, ashes, peat, carbonized rice husk and rice husk ash), was purchased on the local market.

After sowing, the tubes were incubated at $25^{\circ} \mathrm{C}$. Irrigation was done manually, through absorption, keeping the same water blade for all the blocks to obtain the same amount of water.

Seedling emergence: evaluated 15 days after sowing. Normal seedlings were counted as those with at least $3 \mathrm{~mm}$ aboveground. Results were expressed as the percentage of seedlings emerged.

Speed of emergence index: performed according to the conditions previously described.

Total seedling length: all seedlings obtained from the seedling emergence test were harvested and measured for total seedling length (shoot and root), using a ruler graduated in millimeters.

Number of leaves: the number of leaves of all seedlings emerged was counted.

The experimental design used for this stage was randomized complete block design with four replicates.

Data from the two stages were compared by the Scott-Knott test at the $5 \%$ probability level. The software package used to analyze the data was SASM_Agri. In an attempt to demonstrate the efficiency of the methodologies tested, the Person correlation was calculated between the results obtained using different substrates and depths with the results from the seedling emergence and the speed of emergence index.

\section{Results and Discussion}

The physical and physiological quality of pearl millet seed lots used in the study is presented in Table 1 . Germination differed between lots, wherein lots 1, 2 and 5 were classified as the best quality, followed by lots 3 and 4. These results were expected, in the evaluation of a new methodology lots with different germination in which the vigor analysis stratify the two levels of initial physiological quality.

The variable first count of germination ranked seed lot quality in the following order: 1 and 5 (superior quality); 2 and 3 (intermediate quality) and 4 (inferior quality). Thus, the first count of germination provided greater stratification of seed lots when compared to the germination test.

Data from Silva et al. (2017) points out that seed lots with high germination not necessarily present high vigor. Accordingly, one of the major limitations of the germination test is to identify differences in physiological potential between seed lots with high germination, which occurs due to the optimum conditions of the test allowing seed lots to express the maximum number of normal seedlings.

For vigor tests, such as AA, FE and SEI, lot 5 presented the best quality, followed by lots 1 and 2 . The seed lots with the lowest vigor were 3 and 4.

Souza et al. (2009) stated that AA is the most drastic vigor test because of the increase in water content during the exposure period where water imbibition by the seed occurs at different speeds causing a great stress, that is, seed metabolism is exposed to high temperature and humidity. 
There are studies that assert that the seedling emergency tests and, consequently, the emergency speed index, when carried out according to the indications of depth and row spacing for the crop, provide rapid germination and emergence of the seedlings, which become less vulnerable to adverse conditions and spend less time at the initial stages of development (Amaro et al., 2006). In addition, the results of the present study are consistent with the results obtained in the literature.

For the SL test (Table 1), there was no statistical difference between lots which were not classified in different levels of quality. However, for RL and TL, there were significant differences, highlighting seed lot 4 with the lower vigor. However, Amaro et al. (2015) affirm that seedling length test is not sensitive enough to differentiate seed lots by vigor.

Table 1. Initial physical and physiological quality of pearl millet seed lots: first count of germination (FCG), germination (G), accelerated aging (AA), seedling emergence (SE), speed of emergence index (SEI), shoot length (SL), root length (RL), total length of seedlings (TL), water content (WC). Pelotas-RS, 2016

\begin{tabular}{|c|c|c|c|c|c|c|}
\hline Lot & FCG (\%) & G (\%) & AA (\%) & & SE (\%) & SEI \\
\hline L1 & $84 a^{*}$ & $89 a^{*}$ & $78 b^{*}$ & & $72 b^{*}$ & $8.49 b^{*}$ \\
\hline L2 & $69 b$ & $88^{\mathrm{a}}$ & $65 \mathrm{c}$ & & $74 \mathrm{~b}$ & $8.61 \mathrm{~b}$ \\
\hline L3 & $72 b$ & $74 \mathrm{~b}$ & $66 c$ & & $68 \mathrm{c}$ & $8.04 \mathrm{c}$ \\
\hline L4 & $63 c$ & $71 \mathrm{~b}$ & $60 \mathrm{~d}$ & & $68 \mathrm{c}$ & $7.58 \mathrm{~d}$ \\
\hline L5 & $88^{\mathrm{a}}$ & $93^{\mathrm{a}}$ & 81a & & $85^{\mathrm{a}}$ & $10.25 \mathrm{a}$ \\
\hline Mean & 75 & 83 & 70 & & 73 & 8.59 \\
\hline CV (\%) & 3.6 & 4.7 & 2.59 & & 3.44 & 2.85 \\
\hline Lot & $\mathrm{SL}(\mathrm{cm})$ & $\mathrm{RL}(\mathrm{cm})$ & & TL $(\mathrm{cm})$ & & WC (\%) \\
\hline L1 & $4.69^{\mathrm{NS}}$ & $11.61 \mathrm{a}^{*}$ & & $16.29 \mathrm{a}^{*}$ & & 12.78 \\
\hline L2 & 4.94 & $11.37 \mathrm{a}$ & & $16.31^{\mathrm{a}}$ & & 10.5 \\
\hline L3 & 4.39 & $10.79 a$ & & $15.18^{\mathrm{a}}$ & & 8.9 \\
\hline L4 & 4.08 & $9.17 \mathrm{~b}$ & & $13.26 \mathrm{~b}$ & & 8.1 \\
\hline L5 & 4.58 & $10.90 \mathrm{a}$ & & $15.48^{\mathrm{a}}$ & & 13.1 \\
\hline Mean & 4.54 & 10.77 & & 15.3 & & 10.67 \\
\hline CV (\%) & 12.55 & 9.23 & & 8.34 & & \\
\hline
\end{tabular}

Note. Means followed by the same lowercase letter in the column do not differ significantly at $5 \%$ probability level by Scott-Knott's clustering model.

* significant at $5 \%$ probability level, ns $=$ not significant.

\subsection{Seedling Emergence on Different Substrates and Depths}

Results regarding the SEI are presented in Figure 1, where the substrates sand and carbonized rice husk (CRH) at the depth of $1.0 \mathrm{~cm}$ presented the best results for seed lot 5 . These results correlate to those found in the seedling emergence (Table 1). However, for the substrates coconut fiber (CF) and S10 Beifort ${ }^{\mathbb{B}}$, opposite results were verified, as the substrates promoted the performance of seed lots with lower quality. These results can be attributed to the physical and chemical characteristics of both substrates, such as a greater specific surface area for contact between the seed and the substrate and, additionally, due to higher values of electrical conductivity, which is caused by the release of organic and inorganic ions to the solution (Figure 1).

According to Alves et al. (2015), for the germination process to occur in any type of substrate, the water reserve must be maintained time enough for the emergence of the seedlings. According to Kampf et al. (2006), the physical and chemical properties of the substrate, as the water retention capacity, are extremely important for plant management, as this variable assist in determining the amount of water to be used for irrigation. In this work, the higher water retention was observed for the S-10 Beifort ${ }^{\circledR}$ substrate, followed by CF and CRH (Table 1).

Seedling emergency is one of the most widely used vigor tests, which is attributed to a greater similarity with the development of the plant in the field (Grzybowski et al., 2015). The speed of emergence index can be efficient in classifying lots at different levels of vigor, by placing the seeds in adverse climatic and soil conditions (Alves et al., 2012). 

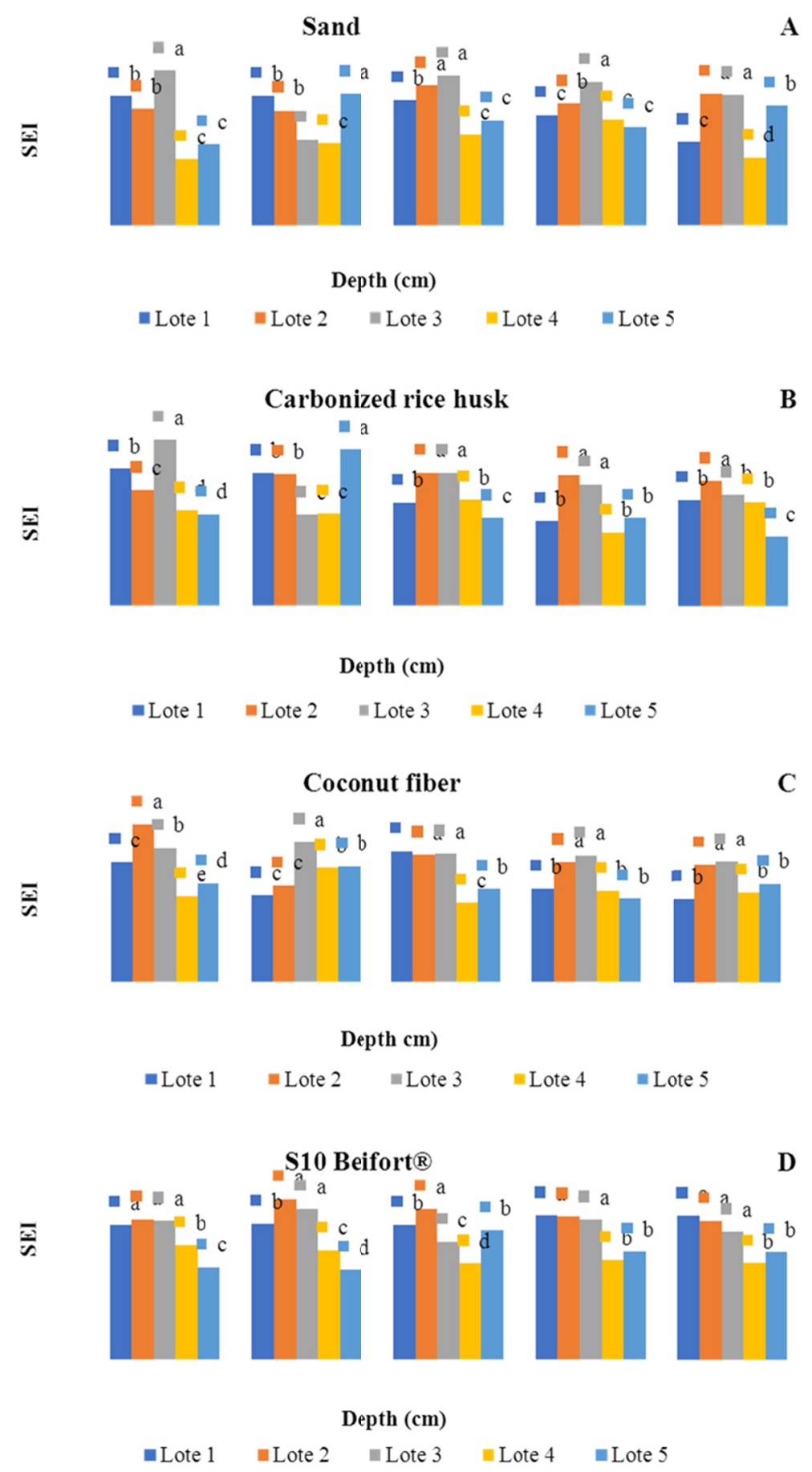

Figure 1. Vigor of pearl millet seeds, evaluated by the speed of emergence index (SEI), in five seed lots sown on different substrates and at different depths $(0.5,1.0,1.5,2.0$ and $2.5 \mathrm{~cm})$. UFPel, 2016

The total seedling length (Figure 2) demonstrates seed lot 5 with the best performance in sand in relation to the others, under a depth of $1.0 \mathrm{~cm}$. Additionally, for $\mathrm{S} 10$ Beifort ${ }^{\circledR}$, lot 5 performed better than the others at $2.5 \mathrm{~cm}$ depth. Nevertheless, for the CRH and CF substrates the best performance was expressed in seed lot 1 at the depth of $1.0 \mathrm{~cm}$.

Tests which evaluate seedling development, such as the total seedling length test, are extremely relevant because the aim is to reduce the loss of physiological potential of seeds (Casaroli et al., 2009). According to Alves et al. (2015), the total length test evaluates growth relationship with plant differentiation and, thus, is related to the soil-plant system, having a major morphophysiological importance. 
Godin et al. (2015) points out that seedlings with well-developed root systems present a greater potential for water and nutrient absorption in the field.

Leaf number presented better results at the depth of $0.5 \mathrm{~cm}$ for sand, classifying lots 5 and 1 as the best (Figure 3). Similar results were found for CRH for lot 5 at the depths of 0.5 and $1.5 \mathrm{~cm}$. However, CF at the depth of 2.0 $\mathrm{cm}$ highlighted lot 5 from the others.

\section{Sand}

A

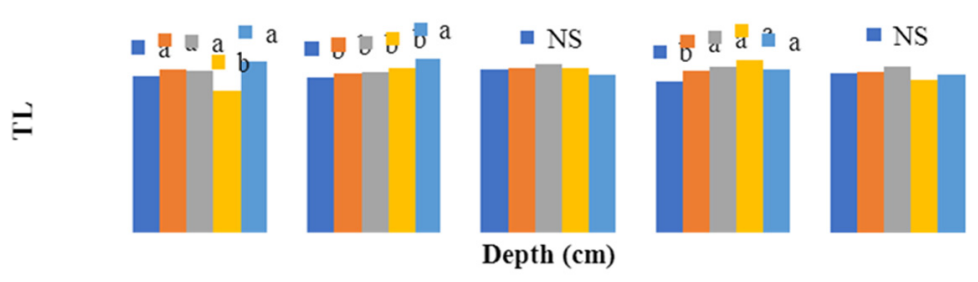

-Lote $1=$ Lote $2=$ Lote $3=$ Lote $4 \quad \square$ Lote 5
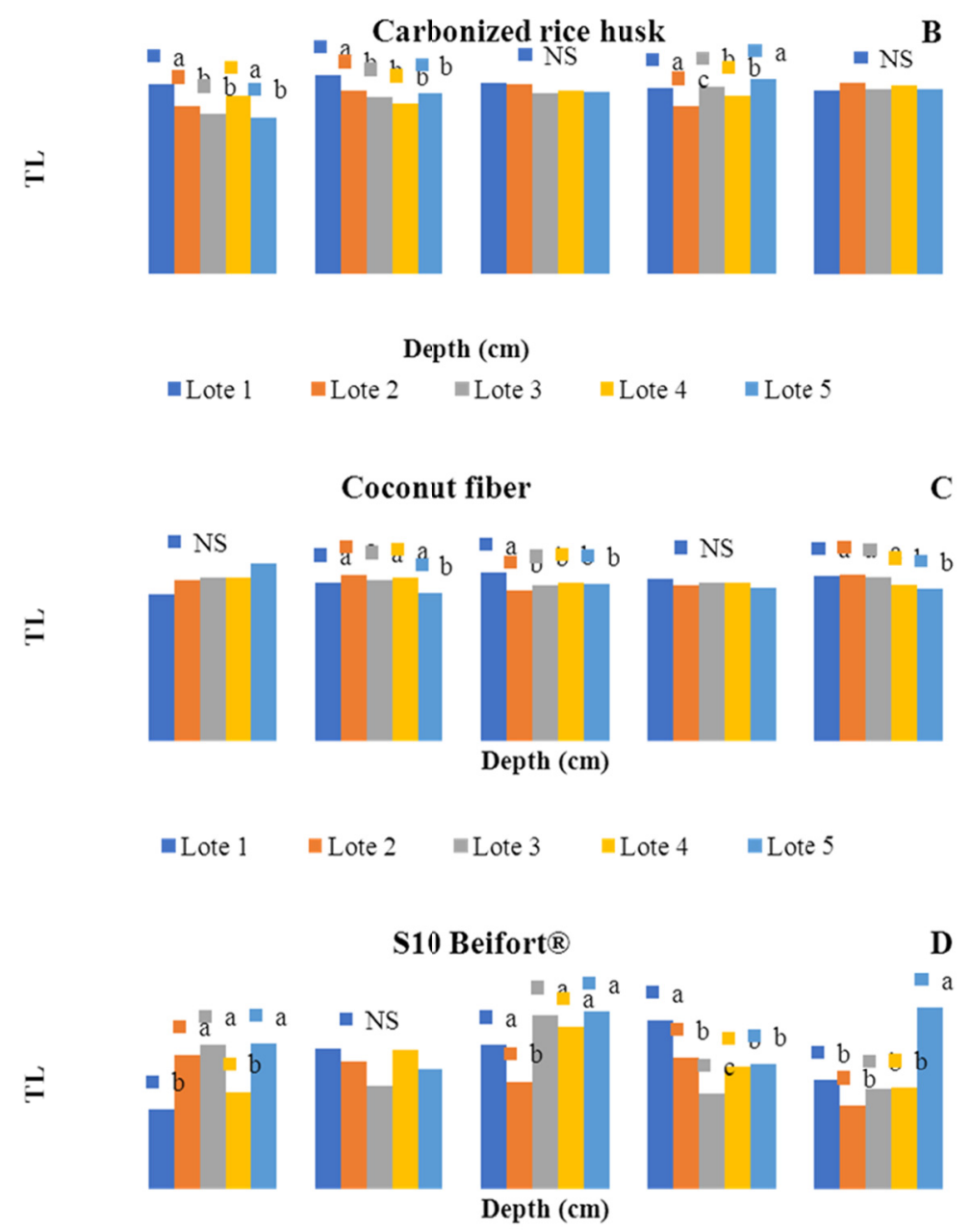

- Lote $1=$ Lote $2=$ Lote $3=$ Lote $4 \quad$ Lote 5

Figure 2. Vigor of pearl millet seeds, evaluated by total seedling length (TL), in five lots of sown on different substrates and at different depths $(0.5,1.0,1.5,2.0$ and $2.5 \mathrm{~cm})$. UFPel, 2016 

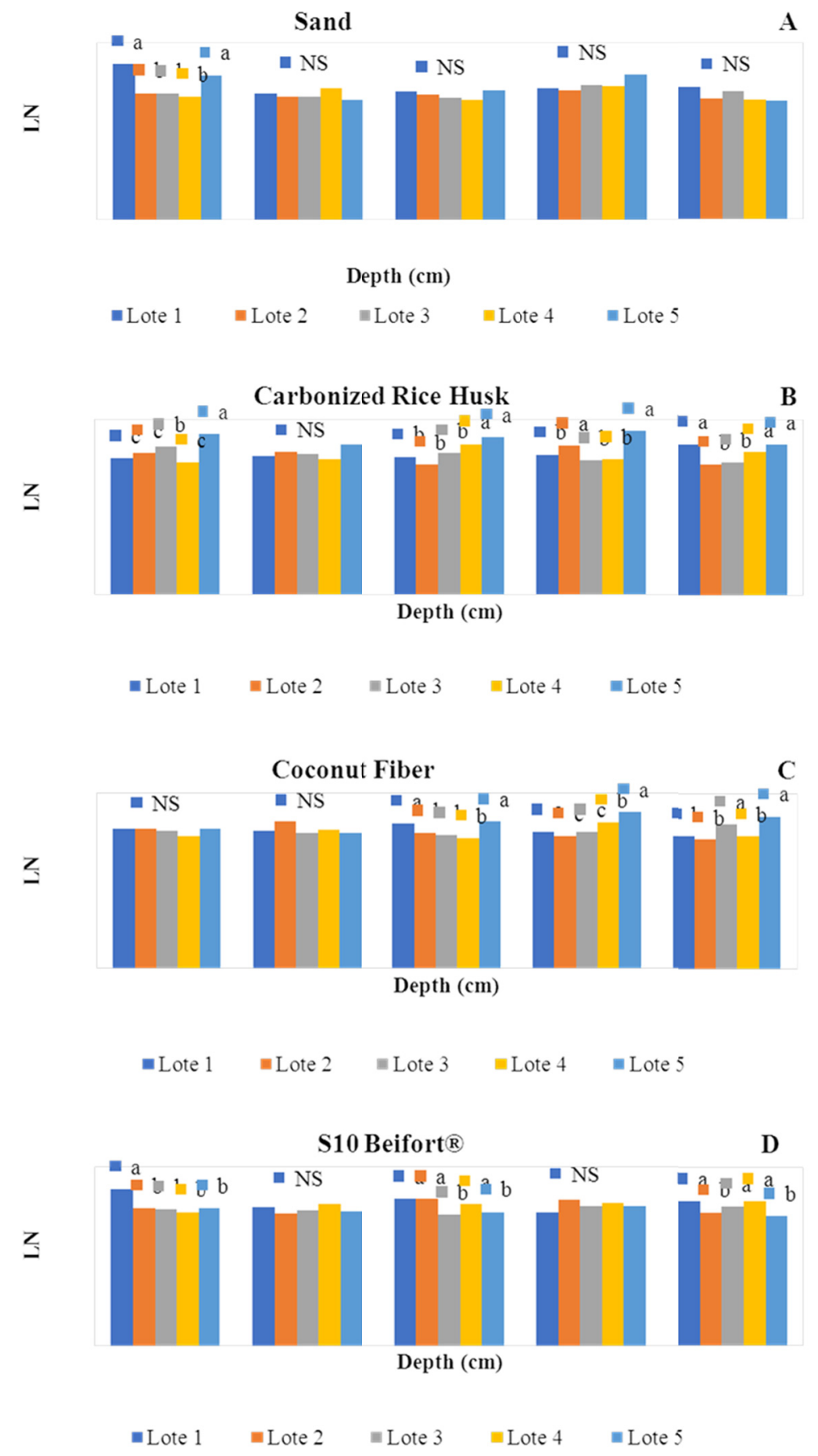

Figure 3. Vigor of pearl millet seeds, evaluated by the leaf number (LN), sown on different substrates and at different depths $(0.5,1.0,1.5,2.0$ and $2.5 \mathrm{~cm})$. UFPel, 2016

Regarding total seedling dry matter (Figure 4), the sand substrate did not show similar results. Similar results were obtained for $\mathrm{CRH}$ at the depths 2.0 and $2.5 \mathrm{~cm}$. For CF, lot 5 outperformed the other seed lots at the depths of $0.5 ; 1.5$ and $2.5 \mathrm{~cm}$ which occurred for $\mathrm{S} 10$ Beifort ${ }^{\circledR}$ at the depth of $1.0 \mathrm{~cm}$.

According to Souza et al. (2009) sowing depth is peculiar to each species and, when appropriate, provides uniformity of germination and emergence. However, Amaro et al. (2015) observed that testing seedling dry matter is efficient for seed lot stratification regarding vigor. Thus, the test is highly viable for the evaluation of seed physiological quality, due to qualities such as ease of achievement, celerity and low cost. The seedling dry matter test can detect small differences in seed vigor due to genotype, seed size and production site, among other factors, allowing greater differentiation of seed lots. 

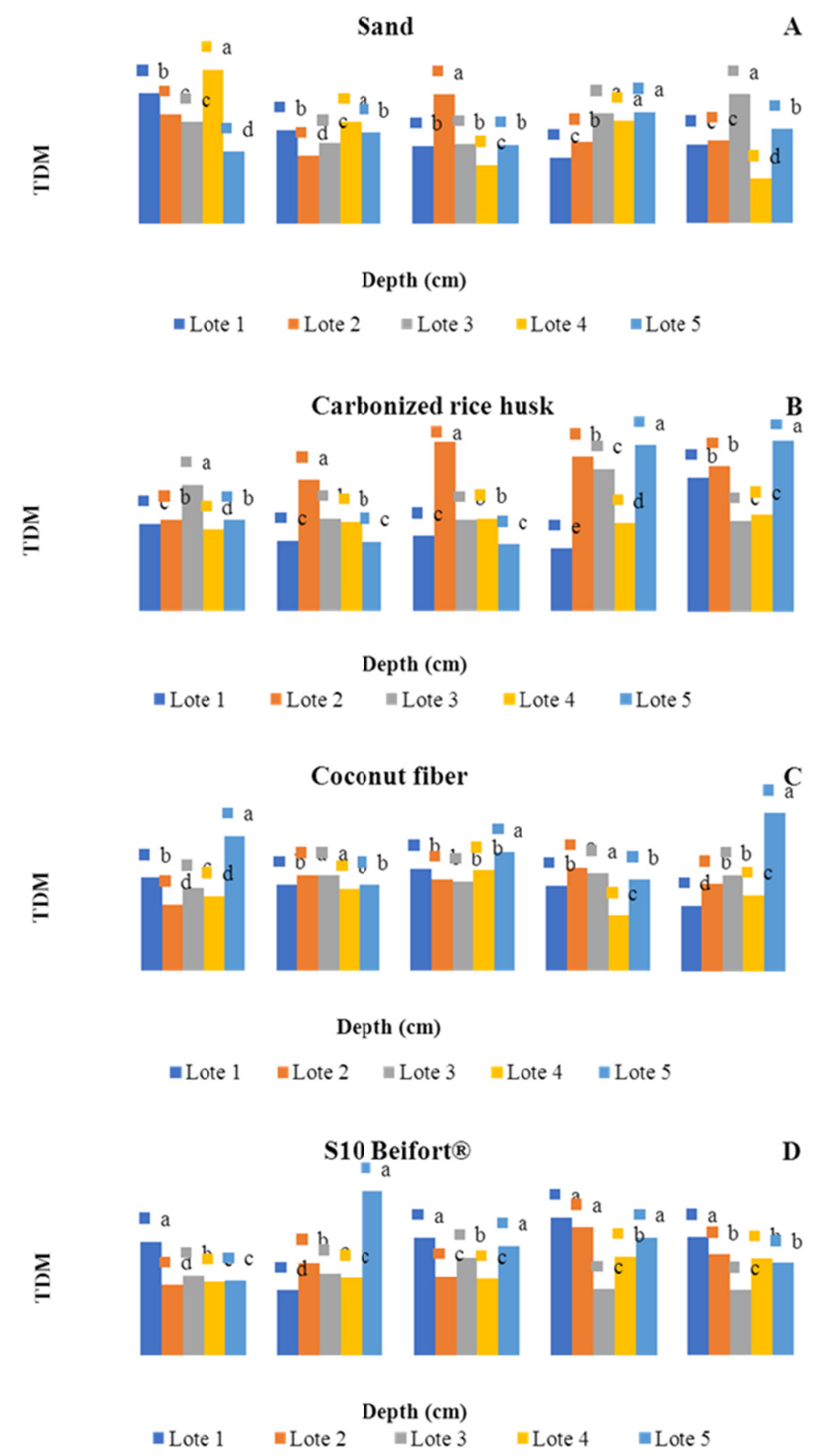

Figure 4. Vigor of pearl millet seeds, evaluated by total dry matter (TDM), of five seed lots sown on different substrates and at different depths (0.5, 1.0, 1.5, 2.0 and $2.5 \mathrm{~cm})$. UFPel, 2016

Table 3 presents the correlation between the speed of emergence index in the substrates tested with seedling emergency and speed of emergency index under regular conditions. For sand, a significant correlation at the 5\% probability level was verified at depths $1.0 ; 1.5$ and 2.0 for the speed of emergency index and seedling emergency, respectively. For coconut fiber, the correlation was positive, at the $5 \%$ probability level, at the depths of 2.0 and $2.5 \mathrm{~cm}$ for speed of emergence index and at $2.0 \mathrm{~cm}$ for seedling emergence, respectively.

The correlation between total seedling length with SEI and SE is presented in Table 4. At the depth of $0.5 \mathrm{~cm}$ using sand as substrate, total seedling length presented a high positive correlation at the $1 \%$ probability level of $r$ $=0.71$ and $r=0.60$ for the variables speed of emergence index and seedling emergence, respectively. These results demonstrate that seedlings with greater total length present superior vigor. At the depths of $1.0 \mathrm{~cm}$ and 
$1.5 \mathrm{~cm}$, a correlation at the $5 \%$ probability level was observed. However, while the depths of 0.5 and $1.0 \mathrm{~cm}$ presented a positive correlation for the speed of emergence index and seedling emergence, this behavior was not detected at the depth of $1.5 \mathrm{~cm}$ where a negative correlation was observed.

Table 3. Linear correlations [Pearson correlation coefficient (r)] between the conventional methods of vigor testing (SEI and SE) and the speed of emergence index (SEI) of five pearl millet seed lots using alternative depths $(0.5,1.0,1.5,2.0$ and $2.5 \mathrm{~cm})$ and substrates (sand, carbonized rice husk, coconut fiber and $\mathrm{S} 10$ Beifort ${ }^{\mathbb{B}}$ ). Pelotas-RS, UFPel, 2016

\begin{tabular}{|c|c|c|c|c|c|}
\hline Variable & 0.5 & 1.0 & 1.5 & 2.0 & 2.5 \\
\hline \multicolumn{6}{|l|}{ Sand } \\
\hline SEI & $0.41^{\mathrm{NS}}$ & $-0.48 *$ & 0.39 & 0.44 & -0.19 \\
\hline SE & 0.40 & -0.42 & $0.48^{*}$ & $0.47 *$ & -0.31 \\
\hline \multicolumn{6}{|c|}{ Carbonized Rice Husk (CRH) } \\
\hline SEI & $0.69^{* *}$ & $0.59 * *$ & 0.30 & 0.10 & 0.39 \\
\hline SE & $0.61 * *$ & $0.62 * *$ & 0.31 & 0.05 & 0.34 \\
\hline \multicolumn{6}{|c|}{ Coconut Fiber (CF) } \\
\hline SEI & 0.27 & -0.11 & 0.12 & $0.49^{*}$ & $0.52 *$ \\
\hline SE & 0.22 & -0.14 & 0.09 & $0.47 *$ & 0.40 \\
\hline \multicolumn{6}{|c|}{ SIO Beifort ${ }^{-1}$} \\
\hline SEI & 0.01 & -0.30 & -0.23 & -0.09 & 0.05 \\
\hline SE & -0.08 & -0.32 & -0.28 & -0.04 & 0.10 \\
\hline
\end{tabular}

Note. ${ }^{* *}$ Significant by t-test at the $1 \%$ probability level; ${ }^{*}$ Significant by $\mathrm{t}$ test at the $5 \%$ probability level; $\mathrm{ns}=$ Not significant by the $\mathrm{t}$ test.

The total seedling length for the substrate carbonized rice husk did not correlate with the vigor tests SEI and SE, regardless of the sowing depth tested. However, for $\mathrm{CF}$ a positive correlation with $\mathrm{SE}$ at the $5 \%$ probability level was observed at depth of $0.5 \mathrm{~cm}$ and a negative correlation with SEI and SE at the $1 \%$ probability level at the depth of $1.0 \mathrm{~cm}$.

The substrate S10 Beifort ${ }^{\circledR}$ presented an expressive positive correlation of $r=0.73$ and $r=0.74(1 \%$ of probability) for the variables index of emergence speed and field emergence with total seedling length at depth of $2,5 \mathrm{~cm}$.

Table 4. Linear correlations [Pearson correlation coefficient (r)] between the conventional methods of vigor testing (SEI and SE) and the total seedling length (TL) of five pearl millet seed lots using alternative depths (0.5, $1.0,1.5,2.0$ and $2.5 \mathrm{~cm}$ ) and substrates (sand, carbonized rice husk, coconut fiber and S10 Beifort ${ }^{\mathbb{R}}$ ). Pelotas-RS, UFPel, 2016

\begin{tabular}{|c|c|c|c|c|c|}
\hline Variable & 0.5 & 1.0 & 1.5 & 2.0 & 2.5 \\
\hline \multicolumn{6}{|l|}{ Sand } \\
\hline SEI & $0.71 * *$ & $0.48^{*}$ & $-0.54 *$ & -0.26 & 0.02 \\
\hline SE & $0.60 * *$ & $0.50^{*}$ & $-0.56^{*}$ & -0.28 & -0.06 \\
\hline \multicolumn{6}{|c|}{ Carbonized Rice Husk (CRH) } \\
\hline SEI & -0.39 & 0.22 & -0.04 & 0.41 & -0.11 \\
\hline SE & -0.34 & 0.22 & -0.03 & 0.30 & -0.02 \\
\hline \multicolumn{6}{|c|}{ Coconut Fiber (CF) } \\
\hline SEI & 0.42 & $-0.61 * *$ & 0.02 & -0.30 & -0.29 \\
\hline SE & $0.46^{*}$ & $-0.65 * *$ & 0.07 & -0.32 & -0.30 \\
\hline \multicolumn{6}{|c|}{ S10 Beifort ${ }^{-1}$} \\
\hline SEI & -0.43 & -0.16 & 0.14 & 0.08 & $0.73^{* *}$ \\
\hline SE & -0.38 & -0.11 & 0.12 & 0.10 & $0.74 * *$ \\
\hline
\end{tabular}

Note. $* *$ Significant by t-test at the $1 \%$ probability level; $*$ Significant by $\mathrm{t}$ test at $5 \%$ probability level; $\mathrm{ns}=$ Not significant by the $t$ test. 
The leaf number from seedlings emerged in sand correlated, at the $1 \%$ probability level, positively with seedling emergence for 1.5 and $2.0 \mathrm{~cm}$ depth and negatively with the speed of emergence index for the depth of $1.0 \mathrm{~cm}$ (Table 5). The leaf number presented an expressive positive correlation with SE and SEI when CRH was used as substrate at the depths of $0.5(\mathrm{r}=0.69$ and 0.61$)$ and $1.0 \mathrm{~cm}(\mathrm{r}=0.59$ and $\mathrm{r}=0.62)$. These results highlight this methodology as an innovative method to evaluate vigor in pearl millet and possibly, other small seeds. For coconut fiber, the leaf number showed a positive correlation ( $5 \%$ probability) with the variables SEI and SE at the sowing depth of 2.0 and with SEI at $2.5 \mathrm{~cm}$. When S-10 Beifor ${ }^{\circledR}$ was used as substrate, the leaf number did not correlate with the results of SE and SEI in any of the depths tested.

Table 5. Linear correlations [Pearson correlation coefficient (r)] between the conventional methods of vigor testing (SEI and SE) and the leaf number $(\mathrm{LN})$ of five pearl millet seed lots using alternative depths $(0.5,1.0,1.5$, 2.0 and $2.5 \mathrm{~cm}$ ) and substrates (sand, carbonized rice husk, coconut fiber and S10 Beifort ${ }^{\circledR}$ ). Pelotas-RS, UFPel, 2016

\begin{tabular}{|c|c|c|c|c|c|}
\hline Variable & 0.5 & 1.0 & 1.5 & 2.0 & 2.5 \\
\hline \multicolumn{6}{|l|}{ Sand } \\
\hline SEI & $0.41^{\mathrm{NS}}$ & $-0.48^{*}$ & 0.39 & 0.44 & -0.19 \\
\hline SE & 0.40 & -0.42 & $0.48^{*}$ & $0.47 *$ & -0.31 \\
\hline \multicolumn{6}{|c|}{ Carbonized Rice Husk (CRH) } \\
\hline SEI & $0.69^{* *}$ & $0.59 * *$ & 0.30 & 0.10 & 0.39 \\
\hline SE & $0.61 * *$ & $0.62 * *$ & 0.31 & 0.05 & 0.34 \\
\hline \multicolumn{6}{|c|}{ Coconut Fiber (CF) } \\
\hline SEI & 0.27 & -0.11 & 0.12 & $0.49 *$ & $0.52^{*}$ \\
\hline SE & 0.22 & -0.14 & 0.09 & $0.47 *$ & 0.40 \\
\hline \multicolumn{6}{|c|}{ S10 Beifort ${ }^{\mathrm{B}}$} \\
\hline SEI & 0.01 & -0.30 & -0.23 & -0.09 & 0.05 \\
\hline SE & -0.08 & -0.32 & -0.28 & -0.04 & 0.10 \\
\hline
\end{tabular}

Note. ** Significant by t-test at the $1 \%$ probability level; $*$ Significant by $\mathrm{t}$ test at $5 \%$ probability level; $\mathrm{ns}=$ Not significant by the $t$ test.

Seedling dry matter, with sand as substrate, presented a negative correlation at the $1 \%$ probability level for the depth of $0.5 \mathrm{~cm}$. Thus, the dry matter of pearl millet seedlings decreased proportionally with the increase in SEI $(\mathrm{r}=-0.80)$ and SE $(r=-0.75)$ (Table 6). However, when CRH was used as substrate, seedling dry matter positively correlated with SEI and SE at the depths of 2.0 and $2.5 \mathrm{~cm}$ in the $5 \%$ and $1 \%$ probability levels, respectively. Furthermore, using $\mathrm{CF}$ as substrate, seedling dry matter showed positive correlations with the two vigor variables (1\% probability), at depths of $0.5 ; 1.5$ and $2.5 \mathrm{~cm}$. The same behavior was observed using S10 Beifort ${ }^{\circledR}$ at the depth of $1.0 \mathrm{~cm}$. 
Table 6. Linear correlations [Pearson correlation coefficient (r)] between the conventional methods of vigor testing (SEI and SE) and the total dry matter (TDM) of five pearl millet seed lots using alternative depths (0.5, $1.0,1.5,2.0$ and $2.5 \mathrm{~cm}$ ) and substrates (sand, carbonized rice husk, coconut fiber and S10 Beifort ${ }^{\circledR}$ ). Pelotas-RS, UFPel, 2016

\begin{tabular}{|c|c|c|c|c|c|}
\hline Variable & 0.5 & 1.0 & 1.5 & 2.0 & 2.5 \\
\hline \multicolumn{6}{|l|}{ Sand } \\
\hline SEI & $-0.80 * *$ & -0.08 & 0.20 & 0.17 & 0.25 \\
\hline SE & $-0.75 * *$ & -0.02 & 0.19 & 0.24 & 0.14 \\
\hline \multicolumn{6}{|c|}{ Carbonized Rice Husk (CRH) } \\
\hline SEI & $0.59 * *$ & -0.32 & -0.23 & $0.56^{*}$ & $0.82 * *$ \\
\hline $\mathrm{SE}$ & -0.21 & -0.26 & -0.19 & $0.55^{*}$ & $0.82 * *$ \\
\hline \multicolumn{6}{|c|}{ Coconut Fiber (CF) } \\
\hline SEI & $0.82 * *$ & 0.00 & $0.81 * *$ & 0.40 & $0.84 * *$ \\
\hline $\mathrm{SE}$ & $0.87 * *$ & -0.07 & $0.89 * *$ & 0.26 & $0.83 * *$ \\
\hline \multicolumn{6}{|c|}{ S10 Beifort } \\
\hline SEI & -0.08 & $0.86^{* *}$ & 0.30 & 0.40 & 0.08 \\
\hline SE & -0.16 & $0.88 * *$ & 0.37 & 0.39 & 0.14 \\
\hline
\end{tabular}

Note. $* *$ Significant by t-test at the $1 \%$ probability level; $*$ Significant by $\mathrm{t}$ test at $5 \%$ probability level; ns $=$ Not significant by the test.

Given that some response variables produced reduced or non-significant correlation between pre-established vigor tests and the methodologies tested, future studies should examine a greater number of species, enabling infer the inclusion of these methods in the laboratory routine.

\section{Conclusion}

The substrates sand and carbonized rice husk, at $1.0 \mathrm{~cm}$ depth, satisfactorily stratified pearl millet seed lots regarding vigor. These methodologies correlated with the speed of emergence index and seedling emergence. Thus, the study identified an innovative method for testing vigor in pearl millet seed lots.

\section{Acknowledgements}

This work was conducted during a scholarship supported by the International Cooperation Program CAPES at the Federal University of Pelotas. Financed by CAPES-Brazilian Federal Agency, for Support and Evaluation of Graduate Education within the Ministry of Education of Brazil.

\section{References}

Alves, C. Z., Godoy, A. R., \& Corrêa, L. S. (2012). Adequação da metodologia para o teste de germinação de sementes de pitaia vermelha. Ciência Rural, 41, 779-784. https://doi.org/10.1590/S0103-8478201100 5000051

Alves, M. M., Alves, E. U., Araújo, L. R., Araújo, P. C., \& Santos Neta, M. M. S. (2015). Crescimento inicial de plântulas de Adenanthera pavonina L. em função de diferentes substratos. Revista Ciência Agronômica, 46, 352-357.

Amaro, H. T. R., David, A. M. S. S., Assis, M. O., Rodrigue, B. R. A., Cangussú, L. V. S., \& Oliveira, M. B. (2015). Testes de vigor para avaliação da qualidade fisiológica de sementes de feijoeiro. Revista de Ciências Agrárias, 38, 383-389.

Casaroli, D., Garcia, D. C., Muniz, M. F. B., \& Menezes, N. L. (2006). Qualidade sanitária e fisiológica de sementes de abóbora variedade Menina Brasileira. Fitopatologia Brasileira, 31, 158-163. https://doi.org/ 10.1590/S0100-41582006000200006

Gondin, J. C., Silva, J. B., Alves, C. Z., Dutra, A. S., \& Elias Junior, L. (2015). Emergência de plântulas de Schizolobium amazonicum Huber ex Ducke (Caesalpinaceae) em diferentes substratos e sombreamento. Revista Ciência Agronômica, 46, 329-338. https://doi.org/10.5935/1806-6690.20150012

Grzybowski, C. R. S., Vieira, R. D., \& Panobianco, M. (2015). Testes de estresse na avaliação do vigor de sementes de milho. Revista Ciência Agronômica, 46, 590-596. 
Kampf, A. N., Takane, R. J., \& Siqueira, P. T. V. (2006). Floricultura: Técnicas de preparo de substrates (p. 132). Brasília, Brasil.

Leão, F. F., Cancellier, L. L., Pereira, A. V., Ledo, F. J. S., Afférri, F. S. (2012). Produção forrageira e composição bromatológica de combinações genômicas de capim-elefante e milheto. Revista Ciência Agronômica, 43, 368-375. https://doi.org/10.1590/S1806-66902012000200021

MAPA (Ministério da Agricultura, Pecuária e Abastecimento). (2009). Regras para análise de sementes (p. 399). MAPA/ACS, Brasília, Brazil.

Melo, L. F., Martins, C. C., Silva, G. Z., Boneti, J. E. B., \& Vieira, R. D. (2016). Beneficiamento na qualidade física e fisiológica de sementes de capim-mombaça. Revista Ciência Agronômica, 47, 667-674.

Melo, P. A. F. R., Cavalcanti, M. I. P., Alves, E. U., Martins, C. C., \& Araújo, L. R. (2017). Substrates and temperatures in the germination of Eriotheca gracilipes seeds. Revista Ciência Agronômica, 48, 303-309. https://doi.org/10.5935/1806-6690.20170035

Nakada, P. G., Oliveira, J. A., Melo, L. C., Gomes, L. A. A., \& Von Pinho, E. V. R. (2011). Desempenho fisiológico e bioquímico de sementes de pepino nos diferentes estádios de maturação. Revista Brasileira de Sementes, 33, 113-122. https://doi.org/10.1590/S0101-31222011000100013

Silva, R. B., Matos, V. P., Farias, S. G. G., Sena, L. H. M., \& Silva, D. Y. B. O. (2017). Germinação e vigor de plântulas de Parkia platycephala Benth. em diferentes substratos e temperaturas. Revista Ciência Agronômica, 48, 142-150. https://doi.org/10.5935/1806-6690.20170016

Sousa, D. M. M., Bruno, R. L. A., Silva, K. R. G., Torres, S. B., \& Andrade, A. P. (2017). Viabilidade e vigor de sementes de Poincianella pyramidalis (Tul.) L. P. Queiroz pelo teste de tetrazólio. Revista Ciência Agronômica, 48, 381-388. https://doi.org/10.5935/1806-6690.20170044

Souza, S. A., Nakagawa, J., \& Machado, C. G. (2009). Teste de envelhecimento acelerado em sementes de aveia preta. Revista Brasileira de Sementes, 31, 155-163. https://doi.org/10.1590/S0101-31222009000200018

Tunes, L. M., Tavares, L. C., Rufino, C. A., Barros, A. C. S. A., Muniz, M. F. B., \& Duarte, V. B. (2012). Envelhecimento acelerado em sementes de brócolis (Brassica oleracea var. italica plenk). Bioscience Journal, 28, 173-179.

\section{Copyrights}

Copyright for this article is retained by the author(s), with first publication rights granted to the journal.

This is an open-access article distributed under the terms and conditions of the Creative Commons Attribution license (http://creativecommons.org/licenses/by/4.0/). 